\title{
POROČILO Z OCENO O SREČANJU ENEL COST (29.-30. 9. 2014) NA BLEDU
}

\section{Domen KRVINA}

Inštitut za slovenski jezik Frana Ramovša ZRC SAZU

Krvina, D. (2014): Poročilo z oceno o srečanju ENeL COST (29.-30. 9. 2014) na Bledu. Slovenščina 2.o, 2 (1): 76-87.

URL: http://www.trojina.org/slovenscina2.o/arhiv/2014/1/Slo2.o_2014_1_o6.pdf.

Od 29. do 30. septembra 2014 je v hotelu Kompas na Bledu potekalo srečanje ENeL COST. V vlogi lokalnega organizatorja je učinkovito nastopala Trojina, zavod za uporabno slovenistiko. Oba dneva je zaznamovalo sončno in čez dan precej toplo vreme, ki je bilo lepše kot marsikdaj poleti in je zlasti na udeležence iz tujine zelo verjetno napravilo dober vtis (kar s turističnega vidika poleg same izbire kraja ni nepomembno). Nastopilo je štirinajst predavateljev iz več evropskih držav. Predstavitve oz. predavanja so vsak dan potekali od 9:0o do 17:0o s krajšim premorom za kavo in prigrizek ter daljšim za kosilo. Udeležba na srečanju je bila brezplačna. Delovni jezik srečanja je bila le angleščina. Prvi dan srečanja so bile osrednje teme retrodigitalizacija obstoječih starejših zlasti slovarskih priročnikov in starejših besedil, njihovo usklajeno povezovanje, delno tudi izdelava korpusnih virov na njihovi podlagi (npr. za slovenščino v okviru projekta IMP). ${ }^{1}$ Drugi dan so bile osrednje teme način prikaza oz. predstavitve podatkov iz najrazličnejših priročnikov (zlasti ob njihovem povezovanju v enovito celoto na enem spletnem mestu), uporaba izkušenj, izhajajočih iz tovrstnega dela, pri izdelavi novonastajajočih slovarjev (npr. nizozemskega in poljskega), delno pa tudi samodejno pridobivanje podatkov iz oblikoskladenjsko označenih korpusov za slovaropisne potrebe s pomočjo dodelanih regularnih izrazov. Proti koncu srečanja je bilo izpostavljeno tudi

${ }_{1}^{1}$ Prim. http://nl.ijs.si/imp/. Prim. še Erjavec in dr. 2011, Erjavec 2012. Rezultate projekta omenja in presoja tudi Orel 2014: 95-98. 
vprašanje odprtega dostopa (tj. pravice do dostopa do že izdelane slovarske baze in njene nadaljnje uporabe brez (posebnih) omejitev), za katero se je izkazalo, da jasnih oz. enoznačnih odgovorov nanj ni. Nekaj tem oz. njihovo problematiko ( $\mathrm{v}$ navezavi na posamezna predavanja) podrobneje predstavljamo v nadaljevanju. ${ }^{2}$

1 Tema, ki je predstavljala rdečo nit srečanja - kot se je izkazalo zlasti ob njegovem koncu - je bilo povezovanje slovarskih, slovničnih, enciklopedičnih oz. drugih glede vira sorazmerno poljubnih podatkov v čim večjem številu in $\mathrm{v}$ čim večji končni preplet, ki naj predstavlja zaključeno, a hkrati vedno odprto celoto s potencialom za nenehno širjenje. To velja tako za posameznojezikovni kot tudi medjezikovni nivo (npr. projekt DBpedia) 3 - v okviru vseh evropskih jezikov. Pri tem meja med pretežno slovarskimi in bolj enciklopedičnimi (tj. obsežnejšimi in potencialno manj koherentnimi, kot je potrebno za pomenski opis, ki razločuje leksem od drugih najbolj podobnih) podatki ni povsem jasno določena oz. se niti ne določa. Slovnični podatki, kolikor niso neodtujljivi del pomenskega opisa, se zdijo bolj neke vrste dodatek. Podobno velja za možnost oblikovanja skupnoevropskih npr. razlagalnih strategij na podlagi obstoječih oz. nastajajočih tako jezikoslovnih kot tudi slovaropisnih dognanj.

1.1 O sami pripravi, obdelavi in izdelavi vsebin, ki naj bi se povezovale v čim obsežnejši in potencialno odprt preplet, se v nobenem od predavanj ni govorilo izhodiščno oz. obsežneje. Izjemo - vsaj do neke mere - predstavljata predavanji Michaela Zocka in Simona Kreka. Michael Zock je govoril o »dostopu do leksema«, to je zlasti do njegovega poimenovanja na podlagi različnih uporabniških predstav, ki so z leksemom povezane na dokaj različnih jezikovnih ravninah (zlasti fonetično-fonološki,4 skladenjski, zunajbesedilni).

2 S podrobno vsebino posameznih predavanj se je mogoče seznaniti na http://www.elexicography.eu/events/workshops/bled-2014. Posvečamo se le nekaterim od navedenih.

3 Prim. http://dbpedia.org/About.

4 Uporabnik denimo ve, da se določena beseda (na pomenski ravni pogosto povsem nepovezana, npr. rep : žep) izgovarja zelo podobno ali pa celo povsem enako kot druga (npr. 
Simon Krek je izpostavil možnost samodejnega računalniškega pridobivanja zlasti kolokacijskih podatkov iz oblikoskladenjsko označenih korpusov z nizi regularnih izrazov kot ozadjem besednih skic, ki so bili dodelane v okviru dela pri Leksikalni bazi za slovenščino. 5 Iz različnih drugih (npr. enciklopedičnih) virov bi se lahko pri posameznih leksemskih tipih (npr. živali, pripomočki, bolezni itd.) ${ }^{6}$ samodejno pridobivali tudi elementi za izdelavo oz. oblikovanje razlage. Pridobljeni rezultati bi bili podvrženi množičenju in tako prečiščene bi v roke dobil slovaropisec, ki naj bi izvedel končno usklajevanje oz. obdelavo previdoma lahko tudi brez pogostejšega oz. rednega vračanja h korpusu kot viru pridobljenih podatkov. ${ }^{7}$

1.2 Obe omenjeni predavanji ponujata kar nekaj dobrih idej, ki so pretežno leksikografskega značaja. »Dostop do leksema " kot predvidevanje vseh potencialnih predstav, ki jih ima na različnih jezikovnih ravninah uporabnik o leksemu, bi bilo mogoče uporabiti denimo pri zasnovi iskalnika po slovarskih vsebinah, kjer bi bila uporabniku na voljo razčlenjena polja, v katera bi lahko vpisoval svoje védenje o leksemu, iskalnik pa bi mu nato na podlagi vnesenega ponudil kar najboljši nabor kandidatov. ${ }^{8}$ Posebej uporabno se to zdi pri slovarskih vsebinah, ki so izvorno namenjene tujcem, medtem ko je za domače govorce (ki jim sámo poimenovanje leksemov zaradi pogoste rabe načeloma ne povzroča večjih težav) taka potreba predvidoma manjša. Predavatelj sam implementacije ni izraziteje izpostavljal.

Prednost samodejnega pridobivanja kolokacijskih oz. pomenskosestavinskih podatkov ob čiščenju s pomočjo množičenja se kaže v sorazmerno izrazitem časovnem prihranku, kar pomeni pospešitev slovaropisnega procesa. Smiselno

\footnotetext{
lastno ime Java kot otok in računalniški program).

5 Prim. http://www.slovenscina.eu/spletni-slovar/leksikalna-baza.

${ }^{6} \mathrm{Npr}$. žival pripada določeni skupini (potencialni UPS), ima takšne, takšne in takšne lastnosti (potencialni RPS-ji); pripomoček se rabi za to, to in to; za bolezen je značilno to, to in to itd. 7 Okoli 20-minutno končno obdelavo gesla bančnik prikazuje posnetek, ki je del omenjenega predavanja.

8 Prim. npr. Moerdijk in dr. 2008.
} 
pa se zdi opozoriti, da ne bi bilo dobro, če bi imel sam slovaropisec pred očmi le hitrost ob polnem zaupanju tako pridobljenim podatkom, ne da bi jih sproti preverjal v korpusu (vsaj z uporabo besednih skic in klikom na posamezne kolokacije) kot viru zanje. Na to je že na srečanju opozoril slovaški udeleženec in predavatelj V. Benko, ki pravi, da na Slovaškem pri svojem delu izhajajo iz prepričanja, da mora biti slovaropisec s korpusom "soočen « 9 - in to tudi z njegovim drobovjem, ki ga predstavljajo konkordance. ${ }^{10}$ Ob zanašanju na podatke, ki so pridobljeni samodejno in prečiščeni z množičenjem, bi ob slovaropiščevi redakciji kot zaključnem delu torej veljalo predlagati sprotni vpogled v besedne skice in določeno število naključnih konkordanc. Poleg tega se ob soočenosti s konkordancami slovaropiscu, posebej če je hkrati soliden jezikoslovec, porajajo tudi splošnejša, slovnična opažanja, ki lahko pomembno dopolnjujejo že obstoječe ugotovitve.

1.3 Kot se je izkazalo v nadaljevanju, večina novonastajajočih slovarjev (denimo nizozemski, poljski) zaenkrat na samodejnem pridobivanju podatkov še ne temelji. Res je, da to (predvsem pri rastočem poljskem spletnem slovarju Wielki słownik języka polskiego, ki ga je po organizacijski plati predstavil Piotr Żmigrodzki, glavni urednik) povečuje potrebo po številu sodelavcev (zlasti jezikoslovcev leksikografov) ${ }^{11}$ pri slovarju in podaljšuje čas njegove izdelave. A določeno število sodelavcev bo najbrž vedno potrebno, če naj bodo slovarske

\footnotetext{
$9 \mathrm{Tj}$. analiza gradiva naj bo »corpus driven «, ne zgolj »corpus given «.

${ }^{10} \mathrm{~V}$ praksi (denimo ob pregledovanju že izdelanih iztočnic, zlasti za drugim redaktorjem) se pogosto izkazuje, da je redaktor že strukturiranim, urejenim in obdelanim podatkom vsaj do neke mere pripravljen verjeti bolj kot tedaj, ko omenjeno (prvič) dela sam. Ob časovni stiski, ki danes ob pogosti vezanosti jezikoslovno-slovaropisnega dela na projekte lahko postane reden pojav, bi redaktor lahko bil prisiljen opraviti zgolj najosnovnejši pregled pridobljenega (prim. npr. Krvina 2014). Prekomerno zaupanje v pridobljene podatke brez njihovega dodatnega prevejernja se zdi vzporedljivo s študijem, za katerega je zahtevano poznavanje določenega dela in premislek o njem, študent pa bi se s tem delom seznanil preko članka o njem ali celo le iz zapiskov koga drugega - ki je po svoji presoji odstranil vse nepotrebno (podobno kot pri množičenju). Preden bi visokosamodejno pridobivanje podatkov postalo povsem splošna slovaropisna praksa, bi ga veljalo preizkusiti na več obsežnejših projektih, ki bi jih jezikoslovno in slovaropisno ocenilo več jezikoslovno-slovaropisnih smeri oz. usmeritev. 11 Prim. http://www.wsjp.pl/index.php?pokaz=autorzy\&l=1\&ind=o (za Wielki stownik języka polskiego) in http://anw.inl.nl/show?page=help\#overhet (za nizozemski slovar ANW).
} 
vsebine vsestransko kvalitetne in zanesljive.

1.4 Manj prednosti spoznanja iz omenjenih predavanj Michaela Zocka in Simona Kreka prinašajo z izraziteje leksikološkega, pomenoslovnega vidika, tj. pri določanju odnosov (pretežno metonimične in metaforične narave) med pomeni leksema, ${ }^{12}$ za katero se zdi, da mora biti v znatni meri še vedno opravljeno ročno. Analizi razmerij, ki jih leksem izkazuje na pomenski ravni, ni bilo posvečeno nobeno predavanje. Nakazalo ga je le vprašanje vodje srečanja Iztoka Kosma, ki je pri predstavitvi novonastajajočega nizozemskega slovarja ${ }^{13}$ vprašal, ali so kdaj pomislili, da bi na prvo mesto v okviru leksema postavili pomene, ki jih uporabniki iščejo oz. pregledujejo najpogosteje. Odgovor je bil, da zaenkrat ne, morda pa kdaj. S pomenoslovnega vidika bi se sprejetje takšne odločitve zdelo aplikativne, pretežno leksikografske narave. Ob predpostavki, da so uporabniki predvsem materni govorci in da iščejo zlasti manj znane, manj pogoste pomene, bi to pomenilo, da bi se na prvem mestu znašli ti, kar bi porušilo logiko (zlasti) metonimično-metaforičnega pomenskega spuščanja od izhodiščnih pomenov k specializiranim. Lahko pa bi bili pogosto iskani pomeni pri prikazu seveda izpostavljeni kako drugače.

2 Problematiki obsega, strukture oz. strukturiranosti in prikaza slovarskih vsebin se je drugi dan posvečalo zlasti predavanje Gebrich de Jong, ki je potekalo kot predstavitev pregleda, ki naj bi zajel vse glavne značilnosti zlasti spletno dostopnih slovarjev evropskih jezikov. Izkazalo se je, da je stanje zelo različno, da se slovarji med seboj precej razlikujejo, načeloma pa vsi vsebujejo razlage, sinonime, pogosto kvalifikatorje in zglede rabe oz. ponazarjalno gradivo, razmeroma pogosto pa tudi etimološki razdelek. ${ }^{14}$ Stranske oblike besed so omejene na slovarje le nekaterih jezikov (domnevamo lahko, da ob

\footnotetext{
12 Prim. npr. Vidovič Muha 2000: 111-157.

13 Prim. http://anw.inl.nl/search.

14 Ugotovitve so do neke mere primerljive s tistimi, do katerih prihaja ob sicer podrobnejši analizi predvsem mikrostrukturne ravni le slovanskih slovarjev A. Perdih (prim. Perdih 2013).
} 
bogatem oblikotvorju zlasti slovanskih). Izkazalo se je tudi, da ni mogoče izdelati enotne opredelitve »akademskega slovarja «, kar je tudi predstavljalo eno od nalog projekta. Od izhodišča, da naj bi to bil »deskriptivni slovar z navedenimi viri za svoje ponazarjalno gradivo (citate)«, se njegova opredelitev vse bolj bliža »zelo kvalitetnemu slovarju «. ${ }^{15}$ Pregled je zajel tudi več spletišč z zlasti slovarskimi vsebinami. Eno od njih, spletišče Družbe za danski jezik in literaturo, ${ }^{16}$ je v nadaljevanju predstavil Lars Trap-Jensen. Spletišče združuje vsebine, ki se tičejo tako jezika (slovarski priročniki in korpusni viri) kot tudi literature in zgodovine (literarnovedni in zgodovinski opisi). Pri zgodovinski orientaciji nam je v pomoč posebna klikljiva časovnica. $V$ jezikovnem delu je spletišče v znatni meri primerljivo s slovenskim spletiščem Fran, ${ }^{17}$ ki ga bo nov oz. nadgrajen pregled - ki naj bi ga Gebrich de Jong izvedla v letu 2015 - že lahko zajel oz. upošteval.

3 Na tokratnem srečanju predstavljeni pregled pa se - vsaj kakor je Gebrich de Jong zagotovila avtorju tega prispevka med odmorom - ni niti dotikal problematike, ki jo je drugi dan srečanja ob predstavljanju nastajajočega nizozemskega (ANW) in poljskega (WSJP) spletnega slovarja odprl Simon Krek, namreč vprašanja o odprtem dostopu do izdel(ov)anih slovarskih baz. Kolikor je bilo mogoče razbrati iz besed Simona Kreka, pomeni odprti dostop pravico dostopati do že izdelane slovarske baze obenem s pravico do njene nadaljnje uporabe brez (posebnih) omejitev. Odgovori niso bili enoznačni, lahko pa iz njih povzamemo, da odprti dostop kot absolutna oz. samodejno pričakovana kategorija ne obstaja oz. (zaenkrat) ni predviden. Prosti dostop do izdelanih vsebin za uporabnike pa ni vprašljiv. Dostop do slovarske baze ${ }^{18}$ nastajajočega nizozemskega slovarja (ANW) načeloma je mogoč, je pa treba

\footnotetext{
${ }_{15} \mathrm{~V}$ slovenskem okolju bi morda lahko govorili o temeljnem slovarju - zlasti knjižnega jezika kot jezikovne zvrsti, ki ima tako narodnopovezovalno kot narodnoreprezentativno vlogo (prim. npr. Vidovič Muha 2013: 7-8).

16 Prim. http://dsl.dk.

17 Prim. www.fran.si. Do neke mere podobno spletišče predstavlja tudi Termania (prim. http://www.termania.net/).

18 Vsekakor si je na računalnik mogoče prenesti posamezna gesla (denimo v formatu XML).
} 
zanj posebej zaprositi. Nadaljnja uporaba slovarske baze je mogoča, če gre - po besedah predavateljice Tanneke Schoonheim - za »some nice research«; sklepamo torej, da (le) v raziskovalne namene. Pri novonastajajočem poljskem slovarju (WSJP) je odprti dostop, vsaj po besedah glavnega urednika Piotra Żmigrodzkega, še nekoliko bolj otežen. Pridobiti je treba soglasje predstojnika glavnega izdelovalca slovarja, torej Inštituta za poljski jezik Poljske akademije znanosti, zelo verjetno pa tudi predsednika Poljske akademije znanosti kot krovne organizacije; morda bi bilo za nadaljnjo uporabo treba skleniti tudi posebno pogodbo. Videti je bilo, kot da zaenkrat da o odprtem dostopu niti niso razmišljali. Določeni zadržki so glede na visoke standarde, ki naj bi na področju (vsaj moralnih, saj materialne lahko pripadajo tudi npr. financerju) avtorskih pravic veljali v EU, razumljivi. V prihodnosti se bo najbrž tehtalo med pravicami avtorjev do zaščite rezultatov svojega dela in pa pravicami potencialnih uporabnikov, tj. zlasti drugih raziskovalcev, do uporabe znanja in metod, ki jih je kot družbeno pomembno pridobitev smiselno razvijati dalje. Pri tem najbrž nobena pravica ne bo smela biti povsem okrnjena (srednja pot). Kar se tiče prostega dostopa do izdelanih vsebin za uporabnike, pa se zdi, da v prihodnje verjetno ne bo vprašljiv. ${ }^{19}$

4 Za konec si dovolimo krajšo primerjavo med dvema izhodiščno dokaj različnima srečanjema, ki pa se v ciljih (raziskovati jezik oz. pojave v njem čim bolj temeljito, podrobno in natančno) morda niti ne razlikujeta tako zelo, le da je eno naravnano bolj aplikativno, drugo pa znanstvenoteoretično: Od 4. do 6. septembra 2014 je na Filozofski fakulteti Univerze v Ljubljani potekalo zasedanje Komisije za slovnično zgradbo slovanskih jezikov pri Mednarodnem slavističnem komiteju. Izsledki večine nastopajočih so izhajali iz sorazmerno natančnih analiz gradiva manjšega do srednjega obsega $\mathrm{z}$ upoštevanjem vseh relevantnih predhodnih spoznanj. Navedeno velja tudi za znanega ruskega leksikologa in leksikografa J. Apresjana, ki kljub delu z obširnim korpusnim

\footnotetext{
19 Prim. tudi Erjavec 2009.
} 
gradivom svoje izjemno podrobne pomenske členitve ${ }^{20}$ navadno izvaja na izbranem gradivu manjšega obsega, ki je za ročni pregled obvladljiv.

4.1 Gre pravzaprav za tradicijo, ki se je v našem, širše pa srednjeevropskem oz. tudi slovanskem prostoru uveljavila že z Miklošičem, zlasti pa pozneje s Škrabcem in Breznikom, ki v svojih razpravah navajata za tiste čase dokaj obširno, vedno pa temeljito pregledano gradivo, iz katerega izvajata svoje ugotovitve. Zdi se, da ob današnjih perspektivnih možnostih samodejnega pridobivanja podatkov te tradicije ne bi smeli zanemarjati, marveč bi bilo smiselno spajati oba pola (kot to do neke mere uspeva Apresjanu).

4.2 Velja se tudi vprašati, ali si ob človeku kot predvidenem uporabniku bolj želimo tisoče vsestransko obdelanih, preverjenih oz. dobro intepretiranih podatkov z jasnimi medsebojnimi razmerji ali pa na milijone pridobljenih podatkov, katerih vrednost je za računalniško analizo gotovo neprecenljiva, za človeka pa je lahko njihovo razmerje zaradi velike množine tudi nedoločljivo. ${ }^{21}$

5 Zadnje srečanje ENeL COST prinaša mnoge pomembne ugotovitve zlasti aplikativne, podatkovnopovezovalne in podatkovnostrukturiranostne narave. 5.1 Te zadnje jasno izpostavljajo nujnost primernega (tj. takšnega, ki omogoča sorazmerno kompleksna iskanja s pomočjo regularnih izrazov) strukturiranja tako starejših kot tudi nastajajočih slovarskih vsebin v enem od standardnih formatov (zlasti XML in TEI). ${ }^{22}$ Prav tako se zdi perspektivno samodejno pridobivanje slovarskih podatkov, vendar zlasti ob pogoju, da bi se povezovalo s sprotno uporabo besednih skic, še posebej pa s temeljitim pregledom gradiva manjšega obsega pri sami redakciji. Tako bi se smiselno spajalo vse novo in $\mathrm{v}$

\footnotetext{
${ }_{20}$ Prim. npr. Apresjan 2014: 15-17. Še predlog: omenjenega jezikoslovca slovaropisca bi glede na njegovo bogato znanje in izkušnje vsekakor veljalo povabiti tudi na srečanja ENeL COST. ${ }^{21}$ Podobno je ob opozorilu avtorja tega prispevka, da obstaja nevarnost, da bi se brez trdne jezikoslovne podlage (izhajajoče tako iz obstoječih kot tudi novonastajajočih spoznanj) vsesplošno povezovanje podatkov - npr. v okviru DBpedie - lahko sprevrglo v popoln kaos, na srečanju razmišljal eden od predavateljev, Ilan Kernerman.

22 Prim. tudi Erjavec 2010, Ledinek, Perdih 2012, Logar in dr. 2012.
} 
znatni meri koristno s preverjeno učinkovito tradicijo, ki je omenjena zgoraj.

5.2 Kar se tiče pomenoslovne analize, zlasti pomenskih razmerij znotraj (pa tudi zunaj) leksema, in usklajenosti razlagalnih strategij, se zaenkrat kaže, da mora biti še vedno opravljena ročno. Tako se novonastajajoča, porajajoča se spoznanja lahko naslanjajo na trden temelj tradicije, ta pa se z njimi oplaja in preraja. ${ }^{23}$ Pogumno, inovativno, a preudarno torej v prihodnost! Upoštevati velja tudi, da ima vsak evropski jezik ali pa vsaj območje (npr. Srednja Evropa glede na evropski Zahod) svoje posebnosti. Zato tudi slovarske vsebine precej verjetno ne učinkujejo povsod enako: ponekod (zdi se, da tudi pri nas) je njihov dolgoročni tako jezikovnopričevanjski kot tudi jezikoslovnorazvojni vpliv (lahko) večji in usodnejši kot drugod.

\section{LITERAT URA}

Apresjan, J. D. (2014): Vzaimodejstvie leksiki i grammatiki. Na primere glagola VIDET. V A. Žele (ur.): Zasedanje Komisije za slovnično zgradbo slovanskih jezikov pri Mednarodnem slavističnem komiteju/Zasedanie Komissii po izučeniju grammatičeskih struktur slavjanskih jazykov Meždunarodnogo komiteta slavistov: 15-17. Ljubljana: Znanstvena založba Filozofske fakultete Univerze v Ljubljani.

Erjavec, T. (2009): Odprtost jezikovnih virov za slovenščino. V M. Stabej (ur.): Infrastruktura slovenščine in slovenistike (Obdobja 28): 115-121. Ljubljana: Znanstvena založba Filozofske fakultete Univerze v Ljubljani.

Erjavec, T. (2010): MULTEXT-East and TEI and TEI: an investigation of a schema for language engineering and corpus linguistics. V D. Tufiş, C. Forascu (ur.): Multilinguality and interoperability in language processing with emphasis on Romanian: 19-47. Bucureşti: Editura Academiei Române.

23 Prim. tudi Žele 2014. 
Erjavec, T. (2012): Jezikovni viri starejše slovenščine IMP: zbirka besedil, korpus, slovar. V T. Erjavec, J. Žganec Gros (ur.): Zbornik Osme konference Jezikoune tehnologije, 8. do 12. oktober 2012: 52-56. Ljubljana: Institut Jožef Stefan.

Erjavec, T., Vodopivec, I., in Kodrič, M. (2011): Izdelava korpusa starejših slovenskih besedil v okviru projekta IMPACT. V S. Kranjc (ur.): Meddisciplinarnost $v$ slovenistiki (Obdobja 3o): 121-127. Ljubljana: Znanstvena založba Filozofske fakultete Univerze v Ljubljani.

Krvina, D. (2014): Problematika zgledov v novem slovarju slovenskega jezika (med čim večjo avtentičnostjo in leksikografsko učinkovitostjo). V S. Bergoč, I. Grahek (ur.): Novi slovar za 21. stoletje: E-zbornik prispevkov s Posveta o novem slovarju slovenskega jezika na Ministrstuu za kulturo 12. 2. 2014, Ljubljana, april 2014. Ljubljana: Ministrstvo za kulturo.

Ledinek, N., in Perdih, A. (2012): Uporaba XML-formata v leksikografiji na primeru oblikovanja XML-sheme za Slovar sinonimov slovenskega jezika. Jezikoslovni zapiski 18 (1): 157-176.

Logar, N., Grčar, M., Brakus, M., Erjavec, T., Arhar Holdt, Š., Krek, S., in dr. (2012): Korpusi slovenskega jezika Gigafida, KRES, ccGigafida in ccKRES : gradnja, vsebina, uporaba. Zbirka Sporazumevanje. Ljubljana: Trojina, zavod za uporabno slovenistiko in Fakulteta za družbene vede.

Moerdijk, F., Tiberius, C., in Niedstat, J. (2008): Accessing the ANW Dictionary. V Proceedings of the Workshop on Cognitive Aspects of the Lexicon. COGALEX 'o8: 18-24. Manchester: Association for Computational Linguistics.

Orel, I. (2014): V slovarju o slovarju od Pleteršnika do SSKJ2. Slavia Centralis 2 (2014): 92-98. 
Perdih, A. (2013): Tipologija slovanskih enojezičnih slovarjev. Doktorska disertacija. Mentor Marko Snoj, somentorica Andreja Žele. Univerza v Ljubljani: Filozofska fakulteta.

Vidovič Muha, A. (2000): Slovensko leksikalno pomenoslovje: govorica slovarja. Ljubljana: Znanstveni inštitut Filozofske fakultete.

Vidovič Muha, A. (2013): Moč in nemoč knjižnega jezika. Ljubljana: Znanstvena založba Filozofske fakultete Univerze v Ljubljani.

Žele, A. (2014): Razvoj tudi jezikoslovnih spoznanj temelji na dopolnjevanju in ne na izločanju doseženega. Slavistična revija 62 (2): 269-270.

\section{SPLETNE STRANI}

Jezikovni viri starejše slovenščine IMP. Dostopno prek: http://nl.ijs.si/imp/ (21. 12. 2014).

DBpedia. Dostopno prek: http://dbpedia.org/About (21. 12. 2014).

Leksikalna baza za slovenščino. Dostopno prek: http://www.slovenscina.eu/spletnislovar/leksikalna-baza (21. 12. 2014).

Wielki słownik języka polskiego. Seznam avtorjev oz. sodelavcev. Dostopno prek: http://www.wsjp.pl/index.php?pokaz=autorzy\&l=1\&ind=o (21. 12. 2014).

Algemeen Nederlands Woordenboek. Dostopno prek: http://anw.inl.nl/search (21. 12. 2014).

Družba za danski jezik in literaturo. Dostopno prek: http://dsl.dk (21. 12. 2014). Fran. Slovarji Inštituta za slovenski jezik Frana Ramovša ZRC SAZU. Dostopno prek: www.fran.si (21. 12. 2014).

Termania. Dostopno prek: http://www.termania.net/ (21. 12. 2014). 
To delo je ponujeno pod licenco Creative Commons: Priznanje avtorstvaDeljenje pod enakimi pogoji 2.5 Slovenija.

This work is licensed under the Creative Commons Attribution ShareAlike 2.5 License Slovenia.

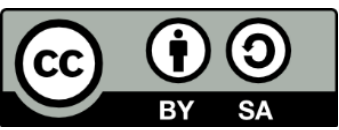

http://creativecommons.org/licenses/by-sa/2.5/si/ 